\title{
OPÓR NATURALNY. AMEREIDA JAKO NIEHEROICZNA WYPRAWA I UNIWERSYTET BEZWARUNKOWY
}

\author{
MAGDALENA BARBARUK
}

\begin{abstract}
Abstrakt: Przez metaforyczne wyrażenie „opór naturalny” autorka wskazuje na wciąż aktualne przekonanie o konieczności odkrywania „morza wewnętrznego” Ameryki Łacińskiej, nieustającego wysiłku „obmyślania Ameryki na nowo” (M.L. Pratt). Przypomina złożone, ambiwalentne, konsekwencje opisów natury A. von Humboldta dla tożsamości i historii Nowego Świata (wzmożenie kulturowych efektów kolonizacji a zarazem wpływ na polityczną dekolonizację kontynentu). Ten historyczny kontekst jest istotny dla rozumienia projektu dekolonizacyjnego zwanego Amereida, w którym wykorzystano „słabe”, tj. poetyckie, artystyczne narzędzia oporu. Barbaruk przedstawia zrealizowaną w 1965 r. przez architektów, poetów i artystów związanych z Universidad Católica de Valparaíso wyprawę (travesía) z Ziemi Ognistej do Santa Cruz de la Sierra (Boliwia) oraz założone przez nich Miasto Otwarte (1970), w którym połączyli pracę, życie i edukację studentów. Podporządkowanie architektury poezji stanowi według autorki praktykę dekonstrukcyjną, która ma na celu realizacje przypisanego uniwersytetowi oporu wobec świata zewnętrznego. Miasto Otwarte stanowić może model „uniwersytetu bezwarunkowego” (J. Derrida), ale też latourowskiego „przedmiotu opornego” (problem odcięcia się grupy od rzeczywistości społeczno-politycznej za czasów dyktatury A. Pinocheta).
\end{abstract}

Słowa kluczowe: Amereida, Ameryka Lacińska, travesía, Miasto Otwarte, uniwersytet. 


\section{Władza słowa}

Uważa się, że w Ameryce Łacińskiej splot zjawisk kulturowych, społecznych i politycznych jest niezwykle silny. W związku z tym refleksja o kulturze musi zawsze uwzględniać jej uwikłanie w rozległy świat heteronomii, zwłaszcza zaś w politykę, tj. wojny, rewolucje, zamachy stanów czy procesy demokratyzacji. Tę słuszną tezę trzeba od razu skonfrontować z - wyglądającym na przeciwny - poglądem mówiącym, że od czasów nowoczesnych jest to obszar „władzy słowa”. Wystarczy prześledzić sposób, w jaki przebiegała kolonizacja, czy rolę, jaką dla formowania i utrwalania się kolonialnego porządku mieli europejscy podróżnicy czy pisarze. Tego rodzaju antynomia cechuje też dzieje Polski, co wiązało się z koniecznością walki wyzwoleńczej, w której wzięło udział wielu poetów, oraz z trwałością ukształtowanego wtedy paradygmatu romantycznego ${ }^{2}$. Nie jest ona jednak dla kultury polskiej tak konstytutywna jak w przypadku utopijnego „kraju przyszłości”3.

W niniejszym artykule chciałabym zwrócić uwagę na fakt, że słowo odegrało w Ameryce Lacińskiej równie ważną rolę, jeśli chodzi o praktyki oporu wobec kolonializmu. Interesuje mnie przede wszystkim zjawisko, które powstało w połowie XX w. i znane jest jako Amereida lub Szkoła z Valparaíso, ale sądzę, że trzeba ukazać je w kontekście procesu politycznej dekolonizacji z początku wieku XIX.

Przywykliśmy okres walk niepodległościowych ujmować w paradygmacie heroicznym. Trudno polemizować z krwią, która przelała armia El Libertadora, Simona Bolívara. Cały kontynent usiany jest pomnikami jego rywala, generała José de San Martina, który ostatecznie spoczą z honorami w katedrze w Buenos Aires. Miejsca bitew wojny niepodległościowej

1 Używam tu wymownego tytułu książki Stanisława Rośka Władza słowa. Sqkice, notatki, świadectwa w oderwaniu od jej materii przedmiotowej. Kontynent południowoamerykański przed jego podbojem był również, choć w innym, bardziej dosłownym znaczeniu, obszarem „władzy słowa”. Chodzi tu o indiańska „kulturę słowa”, która wraz z kolonizacją została poddana nowym, związanym z pismem, wzorcom i matrycom organizacji sensu. Indianie stopniowo włączyli się w zachodnią „kulturę pisma” i „kulturę obrazu” (mapy), a zatem w tworzenie europejskiej wiedzy o Nowym Świecie. Zob. Mignolo 1995 i Pratt 2011.

2 Swoje kraje często wyzwalali poeci. W opisywanym przez Ryszarda Kapuścińskiego przypadku Angoli do uniezależnienia się od Portugalii doszło za sprawą powstałego w 1948 r. ruchu kulturalnego Vamos descobrir Angola (Odkrywajmy Angolę). Młodzi inteligenci wydawali czasopismo literackie Mensagem (Posłanie), które po dwóch numerach zamknęła policja. Przywódcą ruchu i redaktorem pisma był Viriato da Cruz, a jego współpracownikami Agosthino Neto i Mario de Andrade. „Powstanie ruchu wyzwoleńczego Angoli jest dziełem tych trzech poetów" - pisze Kapuściński (2000, 134). Neto stanął na czele Movimento Popular para a Libertacao de Angola. Rozpoczęta w 1961 r. walka zbrojna trwała do 1975 r., kiedy ogłoszono go prezydentem republiki.

3 „Ameryka jest więc krajem przyszłości, którego dziejowa doniosłość ma dopiero objawić się w nadchodzącej epoce” (Hegel 1958, 130). 
funkcjonują jako miejsca pamięci (np. bitwa pod Chacabuco z 1817 r., w której zwyciężyli powstańcy), wielkie znaczenie przypisuje się muzeom historycznym, w przestrzeni publicznej zaś - narodowym bohaterom i flagom. Jeśli jednak zapytamy o punkt zwrotny w historii wyzwolenia Ameryki Łacińskiej, możemy otrzymać odpowiedź związaną z odkrywaniem natury, „morza wewnętrznego” czy tworzeniem toponimów.

Rola, jaką Alexander von Humboldt odegrał dla Ameryki Lacińskiej, nie może być oceniana w sposób jednoznaczny. W Imperialnym spojrz̧eniu Mary Luis Pratt akcentuje znaczenie nieeuropejskiego podróżopisarstwa tworzonego przez Europejczyków po 1750 r. dla legitymizacji imperialnego ładu. Dla badaczki jest Humboldt „człowiekiem oglądającym”, który korzystając ze „strategii niewinności” (praca naukowa i podróżowanie), a zatem nie odwołując się do retoryki imperialnego podboju, utrwalał jego efekty. Prawo Europy do Ameryki przyznawał poprzez tworzenie samowystarczalnych opisów terenów i ludzi, którzy okazywali się w nich „dyspozycyjni”. Pisma Humboldta były kamuflażem dla usprawiedliwienia obecności podróżnika na „niezajętym i nieobciążonym żadnymi roszczeniami terytorium” (Pratt 2011, 256), stanowiły więc zalążek europejskiego ekspansjonizmu. Jednocześnie Pratt przekonuje, by widzieć w nim ikonę procesu transkulturacji, gdyż możemy odczuwać „zdumienie i fascynację faktem, iż pisma Alexandra von Humboldta dostarczyły wizji założycielskich obu tym grupom” (Pratt 2011, 165), tj. elitom północnoeuropejskim i latynoamerykańskim ${ }^{4}$

Jeszcze mocniej władzę słowa w Ameryce Łacińskiej podkreśla efektowna, choć miejscami bezkrytyczna, biografia niemieckiego uczonego autorstwa Andrei Wulf: Cqłowiek, k.tóry zrozumiat nature... Autorka przekonuje, że pięcioletni wysiłek autora Kosmosu, by poznać i opisać „,nowy kontynent”, był kluczowy dla obudzenia lokalnego patriotyzmu, a w konsekwencji również dla procesu politycznego, który doprowadził do wyzwolenia kontynentu spod hiszpańskiej władzy. Wyrazem tego moga być działania i wypowiedzi Simona Bolívara. Nie dowodzę tu konieczności kolonialnej inspiracji w odkrywaniu krajobrazu przez autochtonów, nie neguję szerszych procesów transkulturacyjnych, lecz chcę podkreślić swoistość używanych przez geografa narzędzi, jakimi były fenomenalna pamięć, wyobraźnia, emocje, pracowitość, doświadczenie cielesne związane z chodzeniem czy

\footnotetext{
4 Pratt polemizuje z ujmowaniem romantyzmu jako gotowej ideologii, która promieniowała na peryferia i owocowała wzniosłymi opisami krajobrazu. Casus Humboldta wskazuje, że romantyzm powstał poza Europa i był procesem skomplikowanej transkulturacji wiedzy zachodzącej w tzw. strefie kontaktu.
} 
wspinaniem się, praca „w języku”. A zatem od obserwacji i opisu kształtu liści, koloru gleby czy uwarstwienia skał można poprowadzić drogę do dekolonizacji i zniesienia niewolnictwa.

„Zostały w nas zasiane wspomnienia Humboldta” - stwierdził wenezuelski pisarz i geograf Pascual Venegas Filardo (za: Pratt 2011, 199). „Swym piórem Humboldt obudził Amerykę Łacińską" - mówił Bolívar, wierząc w moc słowa pisanego. Jako potwierdzenie można potraktować to, że El Libertador - podążający śladami Humboldta - wszedł na ekwadorski wulkan Chimborazo. Naśladowanie niemieckiego uczonego nie zadowoliło Bolívara: „porzuciłem ślady Humboldta i zacząłem zostawiać własne znaki na wiecznym krysztale opasującym Chimborazo" - pisał w 1822 r. w poemacie Mi delirio sobre el Chimborazo (za: Wulf 2017, 189). Bolívar przechwycił rozsławiony przez Humboldta wulkan, topos antypodboju, by uczynić z niego symbol rewolucji i wolności. Gdy zapisywał swoją deliryczną wizję, wyzwolił już Kolumbię, Panamę, Wenezuelę i Ekwador. W 1826 r. pisał w uniesieniu, marząc o całym wolnym kontynencie: „Wielki wulkan leży u naszych stóp [...] i jarzmo niewolnictwa zostanie zrzucone" (za: Wulf 2017, 207).

Może wydawać się paradoksem, że pisma Humboldta stały się podstawą ideowa i estetyczną wczesnego (od lat 20. do 40. XIX w.) latynoamerykanizmu, a zatem kreolskie białe elity używały ich do potwierdzenia niezależności tworzonej przez siebie literatury i kultury. Jak pisał Andres Bello, redaktor pierwszego pisma tego nurtu, Repertorio Americano, ukazującego się w Londynie (!) od 1826 r., Ameryka ma pozostać „ziemią Kolumba”, a jednocześnie dokonywać swojego „obmyślania na nowo” (Pratt 2011), które nie może dokonywać się bez europeizujących (europeizante) treści. Humboldtowski topos krajobrazu pojawiał się w tekstach José Martíego, Estebana Echeveríi, Domingo F. Sarmienta. Chyba nigdy go nie przezwyciężono: Gabriel García Márquez wskazywał na pisma niemieckiego geografa jako źródła obrazu Ameryki w perspektywie realizmu magicznego.

\section{Oporne „morze wewnętrzne”}

Pratt wyznaczyła cezurę dla swoich badań retoryki podróżopisarstwa w połowie XVIII w., gdy porzucono pisanie o Nowym Świecie w perspektywie morskich wypraw i zwrócono się w stronę eksploracji interioru (zwykle jej celem była wiedza o surowcach naturalnych). Autorka założyła też, że te zmiany pisania interpretować można jako oznakę transformacji kulturowej dotyczącej samopostrzegania się Europy oraz jej roli w świecie. Interesująca 
metafora, która pojawia się stale od tamtego czasu w dziejach południowoamerykańskiej autonarracji, jest „morze wewnętrzne” (Bolívar mówił o „burzliwym morzu” i „orzących morze" bojownikach, zob. Wulf 2017, 190).

Obraz ten powrócił w filozofii grupy, której celem było „nowe założenie Ameryki” poprzez jej poetyckie ufundowanie i „zamieszkanie”. Jej członkowie uważali siebie za pionierów, można więc ich działania widzieć w kontekście gestów Kolumba, Humboldta czy Bolívara, w perspektywie zjawisk, w których słowa były używane jako czynnik sprawczy, mający wywołać kulturowe konsekwencje. „Ta krucjata żywej poezji da nowy język, Amereidę, będzie Eneida Ameryki [...]. Wyprawa będzie prawdziwą podróżą »mitycznopoietycznąu, z której Ameryka wyjdzie odmieniona” (Berríos 2016, 27). Wydany dwa lata po wyprawie poemat, nazwany od połączenia słów „Ameryka” i „Eneida” Amereidq, jest przez uczestników projektu i ich ideowych spadkobierców traktowany jako nowy mit założycielski Ameryki.

Dziesięcioosobowej grupie architektów, poetów, filozofów, rzeźbiarzy, która 30 lipca 1965 r. wyruszyła niebieskozielonym chevroletem z Ziemi Ognistej do boliwijskiego miasta Santa Cruz de la Sierra, przewodzili argentyński poeta Godofredo Iommi i chilijski architekt Alberto Cruz. Związani byli z Uniwersytetem Katolickim w Valparaíso, gdzie od 1952 r. tworzyli na polecenie rektora, jezuity R.P. Jorge Gonzáleza, Instytut Architektury. W wyprawie zwanej Travesía do nowej „stolicy poetyckiej kontynentu”, wyznaczonej przez nałożony na odwróconą mapę Ameryki Krzyż Południa, realizowali akty poetyckie, które nazywali phalènes. Podróż trwała do 15 września 1965 r. i nie miała wyznaczonej trajektorii. Dla grupy ważne było oddalenie się od brzegów Ameryki (symbolu kolonizacji), odkrywanie „wewnętrznego morza” kontynentu, które uczestnicy uważali za „nieznane”: „Wnętrze Ameryki jest naszym nieznanym, naszym chaosem, naszym morzem” (za: Exposición 20 años... 1972, 28) - mówił Iommi, autor ksiażki Buscadores de lo desconocido (Poszukiwacze niez̧nanego)5.

Koncentrowanie się na nieznanym wnętrzu Ameryki jest zgodne z historią kartowania terytorium kontynentu. Pierwszy raz Ameryka pojawiła się na mapie dzięki Martinowi Waldseemullerowi piętnaście lat po jej odkryciu. Kartograf miał do dyspozycji relację Ameriga Vespucciego (Mundus novus), portolany Nicola Caveriego, na których zaznaczono nowo odkryte obszary lądów, hiszpańskie oraz portugalskie dzienniki pokładowe. Thomas Berg stwierdził, że - biorąc pod uwagę powyższe dane - kształt kontynentu był

\footnotetext{
5 Podstawę książki stanowi wygłoszony w 1979 r. wykład o tym samym tytule.
} 
zdumiewająco poprawny oraz że: „Wzdłuz wybrzeża zaznaczono wiele ujśc rzek i nazw miejscowósci - w głębi lądu nie zwraca uwagi zadna nazwa, cześśc zachodnia zaś to terra ultra incognito" (Berg 2018, 115, podkr. MB).

Wnętrze kontynentu spowijała aura tajemnicy także $\mathrm{z}$ powodu długotrwałego obsesyjnego lęku Hiszpanów przed dopuszczeniem innych do eksploracji. W związku z tym do Ameryki wysyłano szpiegów mających udawać handlowców, publikowano nawet plotki i przestarzałe jezuickie relacje. Strategię Hiszpanów, która miała izolować ich amerykańskie posiadłości, udało się przezwyciężyć dopiero w 1735 r., kiedy Filip V zezwolił na badania naukowe międzynarodowej ekipy. Przeszły one do historii jako „wyprawa Charles’a la Condamine'a". Celem wyprawy było ustalenie prawidłowego kształtu globu. Nie zmieniło to jednak stanu wiedzy o głębi lądu, gdyż w tej wyprawie

nie powiodło się niemal wszystko [...]. Międzynarodowa współpraca przemieniła się w nieustanne potyczki z miejscowymi władzami kolonii, w których spierano się o to, co można, czego nie można zobaczyć, zmierzyć, narysować, czy też z czego pobrać próbki. [...] Badania głębi lądu okazywały się jeszcze upiorniejszym koszmarem politycznym niż poprzedzające je badania morskie (Pratt 2011, 39).

Prawie nikt nie przeżył wyprawy.

Humboldt podtrzymywał wyobrażenie Ameryki jako „pierwotnej natury”, mimo że w eksploracjach korzystał z istniejących dróg, kolonialnej infrastruktury oraz pracy ludności zamieszkującej rzekomo dziewicze tereny. Kontynent opatrywał przymiotnikiem „nowy” mimo trzystu lat, które upłynęły od jego podboju. W obrazie Ameryki, który się wtedy ukształtował, nie było miejsca na historię. „My też mamy już przeszłość” - mogłaby powiedzieć miejscowa ludność akcentując, płynąca z bycia podmiotem dziejów siłę sprzeciwu (zob. Mościcki 2015). „Morze wewnętrzne” pozostawało więc obce także dla samych Amerykanów, którzy zamiast świadomości historycznej dzielili z Europejczykami „świadomość planetarną. Pratt wykazuje, że jeszcze ponad 150 lat po „geście Humboldta” latynoamerykańscy twórcy nie wyzwolili się z traktowania krajobrazu jako pierwotnej natury, którą trzeba „obmyślić na nowo”. W tym sensie można mówić, że w latach 60. ubiegłego wieku grupa Amereida zajęła miejsce niemieckiego geografa: „zostawiając w tyle jego ślady”, opierając się na własnej subiektywności i filozofii przestrzeni, wprowadzając historię na scenę, 
parafrazując humboldtowskie opisy krajobrazu, wpisała się w ustanowioną przez niego tradycję. Zastanawiające jest jednak to, że wśród licznych odniesień do tradycji europejskiej trudno znaleźć w pismach Amereidy odwołania do Humboldta. Niewątpliwie obrazy natury, które pojawiają się w dzienniku wyprawy (Amereida, volumen segundo, 1986), mają też inny status - stanowią raczej podprowadzenie „pod próg” aktów poetyckich. Z drugiej zaś strony dziennik skłania do wniosku, że geonarracja tworzona za sprawą wyprawy była rodzajem artystycznej walki o zajęcie pozycji w historii. Pozycja ta, jak twierdzi Mościcki na podstawie interpretacji obrazów z bitwy pod Borodino zawartych w Wojnie i pokoju Lwa Tołstoja, nie daje się łatwo określić (opozycje typu „władcy - bierne masy” są fałszywe). Trzeba walczyć o „własne wrzucenie w historię”, konstruować jej obrazy, formy, sekwencje, bohaterów, co „wymusza na uczestnikach historii uruchomienie inwencji i sprytu” (Mościcki 2015, 21).

\section{Bezcelowość poetyckiego podboju}

Michel Deguy, francuski uczestnik wyprawy, w eseju filmowym Solo las huellas descubren el mar Javiera Correi, który był częścią wystawy La invención de un mar. Amereida 1965/2017 w Museo de Bellas Artes w Santiago de Chile, mówił, że grupa „podbijała przestrzeń”, ale nikt z uczestników nie używał słowa „konkwista”. Jego zdaniem w tej wyprawie nie było „niczego heroicznego”, gdyż jej miała na celu po prostu posuwanie się naprzód. Dla Francuzów wyprawa nie mogła być politycznym gestem refundacji Ameryki, lecz stanowiła doświadczenie poetyckie, estetyczne, co zresztą oddaje tytułowa inwencja, gdy rozumie się ją jako „wynalezienie”, „wymyślenie”, ale też „urojenie”6.

Grupie chodziło o przeprawę przez środek kontynentu oraz o pozostawienie śladów drogi, którymi były nazwy, artefakty, fotografie, spotkania. „Tylko ślady odkrywają morze” i

\footnotetext{
6 Są również takie sposoby rozumienia ,inwencji”, które powodują, że niewłaściwym wydaje się zwrot „odkrycie”. Na interesujący, etymologiczny trop prowadzi Jacques Derrida, kiedy pisze, że inwencja jest tym, co pojawia się, gdy spotykamy (invenir) innego. „Inwencja polegałaby więc na »umiejętności« powiedzenia "przyjdź« i odpowiedzi na »przyjdź« tego, co inne. Czy to w ogóle się zdarza? Nigdy nie wiadomo tego na pewno" (cyt. za: Markowski 2001, 73). Derrida przygotowania na nadejście innego nazwał dekonstrukcją. Komentujący jego słowa Michał Paweł Markowski interpretuje inwencję jako występującą w spotkaniu (np. czytelnika z tekstem) obustronną relację przemodelowania, niemożliwość odkrycia innego jako innego: „inwencja pozwala potraktować to, co inne, nie jako coś istniejącego na zewnątrz mnie, co domaga się ode mnie (z zewnątrz) zmiany przekonań i nawyków [...], lecz jako to, co w pewnym sensie od środka steruje moim aktem twórczym" (Markowski 2001, 75). Komplementarna wobec inwencji jest zatem odpowiedzialność, tj. odpowiedź na to, co nieznane.
} 
tylko one tworzą szlak. Znamienne, że wędrowcy nie kamuflowali swoich celów w romantycznym estetyzowaniu typowym dla strategii antypodboju, lecz mówili o radykalniejszej sprawczości: odkrywaniu, zmienianiu, zamieszkiwaniu, odwracaniu mapy (powtórzeniu gestu Joaquina Torresa Garcíi, znanego jako przeorientowana mapa: América invertida). W dzienniku wyprawy pisali o podróży „bez celu”, w której toczy się „wolna gra poetycka”: „Wierzymy, że takie »bez celu« naprawdę ujawnia kontynent, jego nieosiągalną Północ, którą wszyscy noszą w sobie, kontynent i Północ” (Amereida II, Bitácora 1986, 48).

Ich podróż nie była zgodnie z rozróżnieniem Javiera del Prado Biezmy ani podróżą odkrywczą, w której celem jest przybycie, a następnie powrót, ani podróżą kolonizacyjną, w której woli przybycia towarzyszy chęć pozostania (taka była mityczna podróż Eneasza). Interesujące jest tu odwołanie Prado Biezmy do poetyckiej podróży odkrywczej, której ideę kreował Victor Hugo w wierszu $A$ M. de Lamartine. Francuz przedstawia Lamartine'a jako pierwszego nowoczesnego poetę odkrywcę. Wyruszył on w podróż na „nieznane ziemie czasownika", a po podróży umiał wrócić triumfalnie do ojczyzny, wzbogacony o zdobyte dobra. Siebie Hugo widział w roli poety odkrywcy zgodnej z aktualną wtedy estetyką i etyką klęski, który szuka dóbr skrywanych na terytorium poezji, ale który „nie wraca triumfalnie, jak Kolumb i Vasco de Gama lub Lamartine, lecz umiera jak francuscy odkrywcy wysp oceanicznych, na nieznanej plaży, z rąk dzikich tubylców” (Prado Biezma 2006, 24). To podróż „bez wiatyku”, prowadząca poszukiwacza przygód do śmierci. Prado Biezma zwraca też uwagę na występującą w wierszu metaforę poetyckiej podróży przez morze. Musi być ona przygoda, gdyż morze jest niestabilne, mimo różnych map nawigacyjnych nie ma na nim dróg, poza tymi wyobrażonymi: „w związku z tym podróż drogą morską nie może być etymologicznie podróżą; bardzo dobrze wyjaśnia to pojęcie esencjonalnego dryfu w praktyce morskiej oraz w praktyce egzystencjalnej (i w pisaniu)" (Prado Biezma 2006, 24-25).

Kategoria dryfu, dérive, była kluczowa dla psychogeografii, którą powołali francuscy letryści z Guy Debordem na czele. Włócząc się nocami po Paryżu, przeprowadzali oni systematyczny eksperyment. Jego celem była krytyka podporządkowanej kapitalizmowi i panoptyzmowi urbanistyki, rewolucyjna „deterytorializacja” związana z rekonfiguracja przestrzeni, zmianą doświadczania miasta. Praktyki dryfowania miały więc kontrkulturowy charakter, choć przeciwne wektory: w Europie chciano wywłaszczenia, wysiedlenia, wygnania (zob. Mościcki 2015, 96-102), w Ameryce Łacińskiej - zamieszkania. 
Latynoamerykański dryf jest też mniej metaforyczny, bo bezpośrednio zakorzeniony w historii morskich wypraw, a więc de facto - także w historii kontynentu.

Błądzenie po paryskich ulicach miało charakter filozoficzny, antropologiczny. Zastanawiano się, jak w wizualnych i językowych reprezentacjach włóczęgi (raportach, mapach) zachować jego rewolucyjność. Tymczasem analiza pisanego zbiorowo w czasie podróży po Ameryce dziennika (Amereida, volumen segundo, 1986) ujawnia szereg figur i obrazów fizycznej słabości: grzęźnięcie w piachu, brnięcie przez wodę, niemożliwość znalezienia drogi lub jej brak, podobną morskiemu dryfowaniu jazdę przez ogromną pampę, przypadki odmowy przyjęcia w gościnę, niezainteresowanie lub niezrozumienie organizowanych przez nich aktów, nieustanne psucie się samochodu, polityczne interwencje w kształt trasy. W dzienniku słowo travesía ma znaczenie praktyczne, oznacza przejście, przesmyk, droge lub most, które trzeba umieć wykorzystać, by pokonać „morze wewnętrzne”: piasek, błoto, śniegi, wodę, karczowiska. Grupa uczy się poruszać po danej nawierzchni, wychodzić z samochodu przed zakopaniem w piasku czy spadnięciem z koleiny, pokonywać odcinki drogi pieszo, wykorzystywać noc do jazdy, spać i jeść w samochodzie, by nie realizować harmonogram (dostosowywanie się do rozkładu promów, umówione z władzami spotkania i „akty”, które przeprowadzane były w miejscowych domach kultury) ${ }^{7}$.

Można tu nawiązać do „cielesnego hexis” (Tim Edensor), czyli technik, których trzeba się nauczyć, by móc wędrować. Sama kategoria wywodzi się od Arystotelesa, który uważał, że cnota jest dobrym przyzwyczajeniem. W jego teorii cnót postawa moralna formowała się w wyniku praktyki życiowej, była nabywaną dyspozycją charakteru do właściwego zachowania się w danej sytuacji, które znajduje się pomiędzy „przesadą” a „niedostatkiem”. Bycie cnotliwym nie wymaga heroiczności. Wyrazem tego była możliwość „rozrzedzenia” cnoty męstwa przez wodza plemienia Wron, gdy skończył się „czas bizonów” i Indianie zamieszkali w rezerwatach. „Człowiek mężny to ktoś, kto osiagnął doskonałość w podejmowaniu ryzyka” (Lear 2013, 130), ale istota ryzyka zmienia się w zależności od

\footnotetext{
7 Grupa Amereidy nie heroizowała brnięcia naprzód, jak czynili to europejscy podróżnicy epoki postwyzwoleńczej, nazywani przez Pratt „kapitalistyczna awangarda”. Dla piewców pragmatycznego wykorzystania natury samo dotarcie do celu (kanoniczny szlak podróży prowadził z portu w Buenos Aires do Limy) było alegoria postępu. W ich opisach wyczerpujących podróży nie ma humboldtowskiego odkrywania „nowego” czy zachwytu natura, jest natomiast „przemysłowe rozmarzenie”: retoryka podboju i osiagnięć. „W wielu relacjach już sama trasa staje się okazją do opowieści o sukcesie, którą jest podróż sama w sobie” (Pratt 2011, 212). Koncentrowanie się na niedostatkach, niewygodach, złej pogodzie, fatalnych drogach, lenistwie tubylców ma podkreślać heroiczność wyprawy zwieńczonej dotarciem do celu i usprawiedliwić cywilizacyjną rolę Europy.
} 
kultury, rozumienie męstwa musi więc być elastyczne, otwarte, słabe. Czasem odważną reakcją na niebezpieczeństwo jest śnienie w imieniu wspólnoty, gdyż oferuje ono wyobrażenie jej przyszłości, innym razem uczenie się od wrogów (w przypadku Amereidy - wykorzystanie kultury europejskiej do zbudowania własnej tożsamości). Lear akcentuje wagę opowieści, wyobraźni i zdolności interpretacyjnej dla odważnego, mierzącego się z rzeczywistościa, zachowania Wron. Te imaginacyjne narzędzia są konieczne w sytuacji, gdy nie możemy wiedzieć, na czym polega sensowne życie, gdyż telos naszej kultury się rozpadł, tradycyjne sposoby życia nie maja już sensu: wtedy „należy działać »w imię« najwyższej wartości, praktycznie angażować się po jej »stronie«" (Lear 2013, XII, podkr. autora). Jest to działanie radykalne, na „łapu-capu”, oparte na logice „być może”, realizujące model „męstwa słabego, osadzonego na ruinach minionego świata” (Lear 2013, XIII).

Twórcy Amereidy filozofowali, jednocześnie angażując się w walkę o dekolonizację Ameryki. Uważam, że w czasie tej trudnej wyprawy reakcja na opór (miejsca, pogody, ludzi, języka) stała się ważnym narzędziem ich „praktyki teoretycznej”, przyczynkiem do określenia roli słowa w przestrzeni, np. zinterpretowania oporu, jaki stawia przyroda, jako wyznacznika metrum poezji.

Wszystko zamarza. Każda próba kończy się niepowodzeniem. W rezultacie, gdy próbujemy się wydostać, samochód wraca do całkowicie zamarzniętego błota. Na każdym kroku niemożność przejścia. Ten moment oświeca nas co do rozumienia podstawy metrum poetyckiego, proporcji relacji części i całości, a raczej kadencji. A pragnienie, by wydostać się ze wszelkich sztuczek, dokonuje się pod egidą języka Kartezjusza. Z powodu obu tych rzeczy, pomiędzy okrzykami i rozkazami, wszyscy mówimy o Kartezjuszu i metrum poetyckim (Amereida II, Bitácora 1986, 48).

Wyraźny opór w dokonywaniu travesía jest sprzeczny z obrazem, który utrwalił się w wyobraźni zbiorowej za sprawą Alejandra Jodorowskiego. W Psicomagia opisywał on powszechne zrozumienie Chilijczyków dla poetyckich, surrealistycznych wypraw miejskich, które wytyczone były zgodnie z linią prostą i czasem wymagały przejścia przez czyjś dom. Takie żądanie poetów spotykało się w latach 50. ubiegłego wieku z akceptacja, gdyż „poezja przesycała wszystko: nauczanie, politykę, życie kulturalne. Sam naród żył cały pogrążony w poezji” i nie było wówczas tak poetyckiego kraju na świecie jak Chile (Jodorowski 1995, 12). 
Spacery poetyckie po ulicach Santiago urządzali w latach 50. młody wykładowca Instytutu Architektury Alberto Cruz i - na jego polecenie - studenci. María Berríos określiła jednak te praktyki jako uniwersytecki „skandal”, godzący w logikę nowoczesności (pędzące po ulicach samochody, jako symbole postępu kraju, miały na nie wyłączność), myślenie o przestrzeni publicznej (ograniczone wtedy do placów publicznych i pasaży) oraz w profesję architekta. Zalecenie Cruza, zadeklarowanego pieszego, by „intymnie” obserwować miasto, uważano więc za niezgodne z misją uniwersytetu, nieuzasadnione w przypadku architekta i niemoralne. Stało się ono jednym ze źródeł najambitniejszego projektu podróży poetyckiej, czyli travesía z 1965 r. Drugim były wyprawy, które postulowało stowarzyszenie poetyckie Iommiego Santa Hermandad de la Orquidea. Założone w 1939 r. w Buenos Aires ugrupowanie miało na celu uwolnienie poezji z pisma ${ }^{8}$. Celem było „życie poezją”. W związku z tym jego członkowie zdecydowali się spalić publicznie, na placu w Buenos Aires, zeszyty z własną poezją i rozpoczać wędrówki poetyckie. Pierwszą z nich zrealizowali w 1941 r., wyprawiając się do brazylijskiej części Amazonii. Tu również można mówić o słabości, gdyż Iommi po dwóch miesiącach musiał przerwać podróż z powodu malarii.

\section{Słabość phalène: apolityczność i nietrwałość?}

Problem porażki wyprawy z 1965 r. poruszyli François Fédier i Michel Deguy przy okazji wspomnianej wystawy w Santiago. Można travesía zarzucić to, że zmieniono ustalone przed podróżą wytyczne, że została przerwana na skutek interwencji boliwijskiego wojska, które obawiało się, że grupa wejdzie na teren opanowany przez partyzantkę Che Guevary. Nie udało się też zrealizować poziomej osi Krzyża Południa. A jednak nie o to chodziło francuskiemu poecie:

8 Warto zadać pytanie, czy idee Amereidy można traktować jako próbę dekolonizacji umysłu, tj. wyrwanie go spod władzy pisma. Dużą część działalności grupy stanowiły wyrafinowane, awangardowe projekty edytorskie i obszerne zasoby archiwum José Vial Armstrong zawierają materiały wskazujące na tezę wręcz odwrotna. A jednak pismo w Szkole z Valparaiso nie zostało sprowadzone do roli cywilizacyjnej, utylitarnej, związanej z komunikowaniem (czegoś, komuś). Pismo zyskało tu swoją względną autonomię, stając się środkiem artystyczno-duchowego wyrazu, narzędziem oporu wobec zachodniego racjonalizmu. 
Porażka? Zatrzymam się przy dwóch sprawach: niewystarczającej relacji (dokumentacji i jej rozpowszechnienia), niedostatecznej refleksji nad oddzielaniem politycznego i poetyckiego, poetyckiego i religijnego, różnicą między „zmianą spojrzenia” (Breton) i zmiana życia [...]. Poezja nie może zastapić Rewolucji [...]. Amereida nie służyła niczemu. Ale miała miejsce (Deguy 2017, 36).

Zdaniem Deguya poezja i polityka nie moga spełniać swoich nadziei. O flasku wyprawy można mówić zatem nie dlatego, że członkowie nie dotarli do Santa Cruz, lecz z powodu statusu języka poetyckiego w jego nowoczesnej, mallarmiańskiej, wizji. „Słabość” travesía byłaby wtedy związana $\mathrm{z}$ autonomią literatury względem jej kulturowo-społecznych zastosowań. Sądzę, że rangę Amereidy można określić lepiej, mówiąc, że znajduje się ponad opozycją „Mallarmé - Marks” (zob. Barbaruk 2018, 165-167). Część uzasadnienia odnajdziemy w estetyce Jacques’a Rancière’a, uznającego „sztukę dla sztuki” za polityczna, bo kreślącą nowe „mapy możliwego”, a jawnie ideologiczną sztukę zaangażowaną za „policyjną”. To w poezji pisanej i czytanej każdego dnia wyprawy zawierały się fundamentalne sensy działań jej uczestników, to te „błądzące słowa” mogły doprowadzić do nowego literackiego „krojenia świata” (zob. Franczak 2017).

Rewolucja poetycka, mimo że Vicente Huidobro w Manifiesto Creacionista porównywał jej siłę do trzęsienia ziemi, może przejść niezauważona. Poezja tworzy świat człowieka (por. kreacyjną „wyobraźnię marząca”" Gastona Bachelarda czy wagę sfery estetycznej u Friedricha Schillera), ale jako jej słabość można poczytywać to, że zmiany wydaja się niewielkie, nieznaczące, ocieraja się o niewidzialność. Akty poetyckie są celowo efemeryczne, przypominają ćmy (słowo phalène oznacza jej gatunek), które spalają się, dążąc do światła. Sam Iommi mówił, że phalène stanowi poiesis (czym nawiązywał do Heideggerowskiego ujęcia phalène jako procesu wychodzenia motyla z kokona) i rytm „gry znikania”. Georges DidiHuberman w Parabole du phalene rozumowal podobnie: „Ćma (phalène) ma nieodzownie błądząca trajektorię, ślepa, niemożliwą do ustalenia, przyciaga ją światło, ale zbliżając swoje delikatne, wątłe ciało, zapala się i ginie”, zmienia się w „maleńką kupkę popiołu” (za: Berríos 2016, 26). Historia aktów poetyckich jest trudna do napisania z powodu ich niematerialności. Przetrwały przede wszystkim jako opowieści obecne w historii mówionej Szkoły oraz jako pewne obrazy utrwalone na fotografiach i w zapisach filmowych. W kontekście powyższego może wydawać się paradoksem, że w czasie wyprawy, z powodu narzędzi i materiałów, które 
wieźli z sobą uczestnicy, często brano ich za murarzy. Byli oni raczej jak myśliwi, którzy nie chcą niczego upolować, tylko przygotowują się do strzału (Amereida II, Bitácora 1986, 51-52)

Fédier porównuje doświadczenie wyprawy do próby teatralnej (ensayo) - „próba, żeby przygotować się do tego, co trzeba będzie zrobić w dniu, kiedy dotrzemy do prawdziwego centrum" (Fédier 2017, 32). Uczestnicy nie wiedzieli, co trzeba będzie zrobić, ale musieli przygotować swoja kondycję, by móc działać. Wieloznaczność hiszpańskiego słowa ensayo czy francuskiego l'essai odsłania jego sens, który - jak przekonuje na podstawie etymologii słowa Michał Paweł Markowski - wiąże się z ryzykiem, w związku z tym „essayer to rozważanie niebezpieczeństwa wpisanego w każde doświadczenie” (Markowski 2001, 52). Phalènes bywaja traktowane jako metoda pracy przygotowawczej, etnograficzne eksploracje konkretnych przestrzeni - metoda przypominająca sposób działania w surrealistycznej etnografii. Jak pisze Berríos, travesía nie była wyprawa oniryczna, lecz podróżą do nowych terytoriów rzeczywistości. Jej wartość tkwiła w samym przebiegu, nie w dotarciu do celu: „Odległości i odwiedzone miejsca są relewantne o tyle, że życie, które się tam toczy, jest konkretną materią i uczestniczy w akcie, a nie dlatego, że są celami czy obiektami kontemplacji”" (Berríos 2016, 26).

\section{Ciudad Abierta jako uniwersytet bezwarunkowy}

Godofredo Iommi i Alberto Cruz wrócili do Chile w 1965 r., gdzie dwa lata później mogli włączyć się w prace nad „Reformą Uniwersytecką”. Ich radykalne postulaty dotyczyły żądania ubóstwa, ascezy i antyhierarchiczności uniwersytetu (należeli do lewicowej Acción Católica). W wyniku ich nieustępliwego stanowiska, decyzją Salvadora Allende, przyznano im 286 hektarów wydm położonych w pewnym oddaleniu od uniwersytetu w Valparaíso i przyległego kurortu Viña del Mar, gdzie znajduje się Wydział Architektury. Założone w 1970 r. w Ritoque Ciudad Abierta - Miasto Otwarte - stało się miejscem, w którym mogli łączyć pracę i życie, uprawiać „naukę nocną"9, uwolnić się od struktur uczelni,

9 Rozróżnienie na „naukę dzienną” (day science) i „naukę nocna”” (night science) opisuje François Jacob w The Statute Within. An Autobiography. Książką tą inspirowali twórcy Amereidy. By nie profesjonalizować wiedzy poprzez ograniczanie jej do sali wykładowej, młodzi architekci, którzy przyjechali w 1952 r. z Santiago do Viña del Mar, zamieszkali wraz z rodzinami na Cerro Castillo. Po 1970 r. Miasto Otwarte umożliwiało uprawianie „nauki nocnej”. 
eksperymentować z formami zamieszkiwania, praktykować deklarowaną od lat 50. ideę architektury jako sposobu życia, a nawet założyć cmentarz.

Gdy poszukujemy praktyk łączących siłę i słabość, mogących stanowić model nieheroicznego oporu, casus utopijnego Miasta Otwartego wydaje się niezwykle obiecujący. Z tej perspektywy najważniejsze jest to, że Amereida powstała w obrębie uniwersytetu i że mimo neoliberalnego kursu, jaki obrało Chile za rządów Augusta Pinocheta, nie została z niego usunięta: terenu Miasta nie sprywatyzowano, nie przymuszono Cruza i Iommiego, by kształcili studentów zgodnie z komercyjnym modelem uczenia architektury (w Szkole z Valparaíso wagę przykłada się do procesu, nie zaś rezultatu, używa się nietrwałych materiałów z recyklingu, uczy nawyku obserwacji, pracuje zbiorowo i nie podpisuje dzieł, fenomenologicznie „wraca się do niewiedzy” (volver a no saber) ${ }^{10}$, na wszystkich etapach pracy obecne są elementy ludyczne $\left.{ }^{11}\right)$.

Jacques Derrida za miejsce uobecniania się uniwersyteckiej autonomii, zasady oporu wobec ekonomii czy polityki, uznaje Humanistykę. Proponuję pójść w stronę mocniejszej ontologii i wskazać na przestrzeń, na którą składają się przyznane Uniwersytetowi wydmy Miasta Otwartego. Sądzę, że miejsce to może stać się figurą opisywanego przez Derridę koniecznego zwrotu w myśleniu o Humanistyce i uniwersytecie we współczesnym świecie. Zdaniem Derridy ma on być „uniwersytetem bezwarunkowym”, opornym wobec tego, co chce naruszać jego autonomię, instytucją, w której wiedza łączy się z wiarą, praca profesora nie jest zawodem, lecz „pewnym poręczeniem, zobowiązaniem, obietnicą, aktem wiary, deklaracją wiary i w efekcie wyznaniem wiary" (Derrida 2015, 28).

Bezwarunkowość jako zasada istnienia, a zatem siła uniwersytetu jest zarazem powodem jego słabości. Działa coraz mniej efektywnie we współczesnym świecie. Gdyby tak nie było, Miasto Otwarte mogłoby być miejscem, gdzie bez przeszkód realizuje się kulturalistyczne, schillerowskie przekonanie o uzależnieniu człowieczeństwa od piękna, będącego przedmiotem ludzkiego „popędu gry”12. Miasto to jest wydzieloną przestrzenia, którą można łatwo odciąć od świata zewnętrznego. Prowadzącą do niej skromną bramę, dwa

10 Berríos zwraca uwagę na podobieństwo emancypacyjnej pedagogiki Szkoły do idei Rancière’a wyrażonych w Mistræu ignorancie (1987).

11 Jeden dzień w tygodniu (środa) w Mieście Otwartym poświęcony jest aktywności fizycznej i zabawom. Ponadto co roku rozgrywane są gry wymyślone przez studentów - proste, przypominające naiwne rytuały.

12, ,[C]złowiek bawi się tylko tam, gdzie w całym znaczeniu tego słowa jest człowiekiem, i tam tylko jest pełnym człowiekiem, gdzie się bawi” - pisze Schiller w Listach o estetycznym wychowaniu cəłłowieka (Schiller 2011, 97). 
słupki z odciśniętym napisem Corporación Cultural Amereida i odwróconą mapa kontynentu, trudno ominą́, gdyż z jednej strony dostępu broni Pacyfik, z drugiej gęste zarośla i ukształtowanie terenu oddzielające miejsce od dość ruchliwej drogi13. Wszystko to czyni granicę pomiędzy zewnętrzem a wewnętrzem uniwersytetu wyraźną i odczuwalną. Dla Derridy granica ta nie pozwala Humanistom zapominać o świecie, co nie może być tylko stwierdzone intelektualnie, lecz musi być również performowane. $\mathrm{Na}$ tej granicy

\begin{abstract}
uniwersytet poddaje się działaniu rzeczywistości sił zewnętrznych (kulturowych, ideologicznych, politycznych, ekonomicznych bądź jakichkolwiek innych). W tym oto miejscu uniwersytet jest w świecie, który próbuje pomyśleć. Na tej właśnie granicy musi zatem negocjować i organizować swój opór. I zarazem wziąć na siebie odpowiedzialność. Nie po to jednak, aby się zamknąć, odgrodzić i przywrócić ów abstrakcyjny fantazmat suwerenności, którego teologiczne i humanistyczne dziedzictwo zacznie być może dekonstruować [...]. Ale przede wszystkim po to, by łącząc się z siłami pozaakademickimi, móc się efektywnie opierać, a dzięki swym dziełom stawić opór twórczą kontrofensywą, wymierzoną we wszelkie próby ponownego zawłaszczenia (politycznego, prawnego, ekonomicznego etc.), we wszelkie pozostałe figury suwerenności (Derrida 2015, 98).
\end{abstract}

W rzeczywistości uniwersytet nie jest bezwarunkowy, ale zgodnie ze swoim powołaniem powinien pozostać miejscem krytycznego i performatywnego, tj. polegającego na praktyce dekonstrukcyjnej, oporu. Dekonstrukcja to istota Humanistyki, bo stanowi rodzaj „obywatelskiego nieposłuszeństwa”, myślenia-działania, zgodnego z wyższym prawem i sprawiedliwościa, co wiąże się z rozszerzaniem obszaru humanistyki o inne dziedziny, także niedyskursywne, m.in. te wytwarzające zdarzenia w postaci tekstów czy dzieł sztuki. Derridzie zależy na tym, by mieć wciąż na uniwersytecie „prawo do powiedzenia wszystkiego”. W takim kontekście - jako dekonstrukcyjne pytanie i praktykę - postrzegam Amereidę jako dekolonizacyjną travesía, regularne studenckie wyprawy odbywane od 1984 r. oraz działania podejmowane w przestrzeni Miasta Otwartego, które godzą w architekturę rozumianą jako profesja.

13 Znamienne, że gdy przyjechałam do Miasta Otwartego w marcu 2019 r., mieszkańcy doświadczyli właśnie pierwszej próby sforsowania i zniszczenia bramy przez nieznanych sprawców. 
„Gdzie dziś, w epoce cyberprzestrzeni komputerowej, cyberprzestrzeni tele-pracy i stron internetowych, znajdują się miejsca wspólnoty oraz cała więź społeczna «kampusu»? pytał zaniepokojony Derrida. Na Uniwersytecie Valparaíso nie zostało zniszczone „doświadczenie posiadania-miejsca”, jak to się stało w środowiskach ulegających „wirtualizacji przestrzeni komunikacji, dyskusji, publikacji oraz archiwizacji” (Derrida 2015, 33). W Mieście Otwartym odbywają się formacyjne zajęcia dla studentów (Taller de Amereida) oraz akty poetyckie, mające po heideggerowsku „otwierać” przestrzeń. Amereida jest przy tym doskonale zmediatyzowana, wirtualna, co wiąże się z istnieniem cyfrowych archiwów, gromadzących i udostępniających teksty (Biblioteca Con』tel), obrazy (Archivo de Juan Armstrong Vial) oraz dźwięk (Arcbivo de la Palabra).

Z uwagi na powyższe aspekty - utopijną bezwarunkowość rozumiana jako refleksyjny i dekonstrukcyjny opór, nieodcinanie się od współczesnego świata (pożądane lub nie), czynienie „granicy” odczuwalną - fenomen Amereidy może być traktowany jako dający do myślenia model uniwersytetu jutra. Wydaje się on figurą lepszą niż topos „czarodziejskiej góry”, mocniej chwytająca ambiwalencję rzeczywistości ludzkiej. Jest tak także dlatego, że za czasów dyktatury Pinocheta doszło do poważnego etycznego podważenia zasadności autonomii omawianych praktyk. Apolityczność grupy została potraktowana wtedy nie jako opór wobec reżimów nowoczesności, lecz wygodna izolacja czy dobrowolne uwięzienie. Jako pierwszy tego rodzaju zarzuty czynił chilijski historyk Alfredo Jocelyn-Holt, jednak to dopiero w tekście pisanym z dystansu, przez Anę Maríę León, uczoną z University of Michigan, wydobyty został niepokojący sens milczenia profesorów. Pisze ona, że w 1974 r., zaledwie 5 kilometrów na północ od Miasta Otwartego, na tym samym wybrzeżu utworzono obóz koncentracyjny dla więźniów politycznych, wśród których dużą grupę stanowili lewicowi aktorzy teatralni. León zauważa, że w obu miejscach używano podobnych środków performatywnych, aby „wytworzyć przestrzeń”, w obu powstały podobne wspólnoty, co skłania ją do określenia tychże grup jako „więźniów Ritoque” (León 2016). Profesorowie i studenci Amereidy stworzyli utopijną enklawę, która uniezależniała od normatywnych struktur uczelni, ale ograniczała ich aktywność polityczna, natomiast więźniowie przekształcali przymusową izolację w opór polityczny. Porównanie León można określić jako efektowne, interesujące, nie wiem jednak, czy rozjaśnia ono problem funkcjonowania uniwersytetu (literatury czy sztuki) w czasie tej ponurej dyktatury. Można mu również zarzucić estetyzację cierpienia więźniów obozu. 
Nie ma tu miejsca, by rozważać etyczny wymiar zaistniałego stanu rzeczy, pytać o ciemną stronę nowoczesnych utopii, zagrożenia płynące ze strony silnych wspólnot skupionych wokół „wiedzy i wyznania” (za Derrida). Idąc za wskazówkami Brunona Latoura, w poszukiwaniu formuły dla humanistyki, która może sprostać skomplikowanemu światu, trzeba wynajdywać „przedmioty oporne”, „obiektywne”, czyli niezależne od zamiarów koncepcyjnych badacza. Dla Ewy Domańskiej jest to przesłanka do tworzenia humanistyki nieantropocentrycznej, ale bez względu na trwałość czy trafność różnych szyldów, propozycja szukania „rzadkich, lokalnych, cennych, niesamowitych sytuacji w których [badacze - przyp. $\mathrm{MB}$ ] becda $\mathrm{c}$ stanie uchwycí podmiot badawczy opierajacy sie, temu, co siec o nim mówi, podmiot niepodporzadkowany, niezdyscyplinowany i taki, który będzie stawiał własne pytania, stawiał własne warunki, a nie wpasowywał sie, w interesy, których nie podziela!" (Latour, za: Domańska 2008, 21), jest uniwersalnie istotna. 


\section{Wykaz literatury}

Amereida, volumen segundo, 1986. Valparaíso: PUCV.

Bachelard, Gaston. 1998. Poetyka marzenia. Tłum. Leszek Brogowski. Gdańsk: słowo/obraz terytoria.

Barbaruk, Magdalena. 2018. „Zabroniona funkcja języka. Przypadek Amereidy.” Konteksty 12: 165-177.

Berg Reinertsen, Thomas. 2018. Teatr swiata. Mapy, które tworzq historie. Tłum. Maria Gołębiewska-Bijak. Kraków: Znak.

Berríos, María. 2016. „Apuntes paratácticos sobre la poesía viva de la Escuela de Valparaíso.” Eremuak 3. http://www.eremuak.net/sites/default/files/eremuak3_imprenta.pdf.

Derrida, Jacques. 2015. Uniwersytet bezwarunkowy. Tłum. Kajetan Maria Jaksender. Kraków: eperons-ostrogi.

Domańska, Ewa. 2008. „Humanistyka nie-antropocentryczna a studia nad rzeczami.” Kultura Wspótczesna 3: 9-21.

Exposición 20 años Escuela de Arquitectura UCV. 1972. Museo Nacional de Bellas Artes, Santiago de Chile.

https://wiki.ead.pucv.cl/images/3/32/OFI_1972_Exposicion_20.pdf.

Franczak, Jerzy. 2017. Bładzace stowa. Jacques Rancière i filozofia literatury. Warszawa: Instytut Badań Literackich.

Hegel, Georg Wilhelm Friedrich. 1958. Wykłady z filozofii driejów. T. 1. Tłum. Janusz Grabowski, Adam Landman. Warszawa: Państwowe Wydawnictwo Naukowe.

Jacob, François. 1988. The Statute Within. An Autobiography. New York: Basic Books Inc. Publishers.

Jodorowsky, Alejandro. 1995. Psicomagia. http://lawerk.com/psicomagia-libro-pdf-gratisjodorowsky/.

Kapuściński, Ryszard. 2000. Jeszzze dzień ṡycia. Warszawa: Czytelnik.

Lear, Jonathan. 2013. Nadzieja radykalna. Etyka w obliczu spustoszenia kulturowego. Tłum. Marcin Rychter. Warszawa: Biblioteka Kwartalnika Kronos.

León, Ana María. 2016. „Prisoneros de Ritoque. La Ciudad Abierta y el centro de detención.” ARQ 92. https://scielo.conicyt.cl/scielo.php?script=sci_arttext\&pid=S071769962016000100009.

Markowski, Michał Paweł. 2001. Wystepek. Eseje o pisaniu i caytaniu. Warszawa: Sic!.

Mignolo, D. Walter. 1995. The Darker Side of the Renaissance. Literacy, Territoriality \& Colonization. Michigan: The University of Michigan Press.

Mościcki, Paweł. 2015. My też, mamy jużprzeszłość. Guy Debord i bistoria jako pole bitwy. Warszawa: Fundacja Bęc Zmiana.

Prado Biezma, Javier, del. 2006. „Viajes con viático y sin viático.” Revista de Filologia Romanica IV: 15-29.

Pratt, Mary Louis. 2011. Imperialne spojrzenie. Pisarstwo podróżnicze a transkulturacja. Tłum. Ewa Elżbieta Nowakowska. Kraków: Wydawnictwo Uniwersytetu Jagiellońskiego.

Todorov, Tzvetan. 1996. Podbój Ameryki. Problem innego. Tłum. Janusz Wojcieszak. Warszawa: Aletheia.

Wulf, Andrea. 2017. Człowiek, który zrozumiał nature. Nowy swiat Alexandra von Humboldta. Tłum. Katarzyna Bażyńska-Chojnacka, Piotr Chojnacki. Poznań: Wydawnictwo Poznańskie. 
Magdalena Barbaruk - kulturoznawczyni, adiunkt w Instytucie Kulturoznawstwa Uniwersytetu Wrocławskiego. Prowadzi badania nad kulturowym potencjałem literatury w kształtowaniu sposobów życia i „mapowaniu” przestrzeni. Autorka monografii: Długi cień Don Kichota (Kraków 2015; ang. The Long Shadow of Don Quixote, Frankfurt am Main 2015), Sensy bładzenia. La Mancha i jej peryferie (Kraków 2018) oraz filmu dokumentalnego Błędne mapy (2014), który powstał jako rezultat projektu badawczego NCN („Fuga”), zrealizowanego w Instytucie Etnologii i Antropologii Kulturowej UJ (2012-2014). Obecnie prowadzi badania nad Amereida, poetycko-architektoniczną „utopia w ruchu” (NCN, „Opus”, 2018-2020). Publikowała m.in. w Kontekstach. Polskiej Sztuce Ludowej, Kulturze Wspótczesnej, Przegladrie

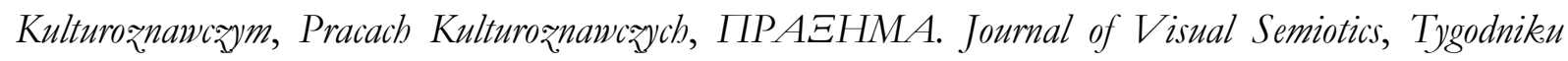
Powszechnym, Kulturze Liberalnej.

\section{DANE ADRESOWE:}

Instytut Kulturoznawstwa

Uniwersytet Wrocławski

ul. Szewska 50/51

50-139 Wrocław

EMAIL: magdalena.barbaruk@uwr.edu.pl

FINANSOWANIE: Tekst został przygotowany w ramach grantu badawczego NCN Trajektorie stowa. Kulturowe oddriaływanie Amereidy (nr 2017/25/B/HS2/00453).

CytowANIE: Barbaruk, Magdalena. 2019. „Opór naturalny. Amereida jako nieheroiczna wyprawa i uniwersytet bezwarunkowy." Praktyka Teoretyczna 2(32): 109-128

DOI: $10.14746 /$ prt.2019.2.6

AUTHOR: Magdalena Barbaruk

TITLE: Natural resistance. Amereida as a non-heroic expedition and unconditional university

ABSTRACT: Through the metaphorical phrase "natural resistance", the author indicates still valid belief in the necessity of discovering the "internal sea" of Latin America, the constant 
effort of "the reinvention of America" (M. L. Pratt). She reminds the ambivalent consequences of A. von Humboldt's descriptions of nature for the identity and history of the New World (growing cultural consequences of colonization and, at the same time, the political decolonization of the continent). This historical context is important for the understanding of the decolonization project called Amereida, in which the "weak", poetic, artistic tools of resistance were used. She describes travesía from Tierra del Fuego to Santa Cruz de la Sierra (Bolivia), carried out in 1965 by architects, poets and artists associated with the Universidad Católica de Valparaíso, and the Open City, founded in 1970, in which they combined work, life and education of students. According to the author, the subordination of the architecture of poetry is a deconstruction practice aimed at achieving resistance to the world assigned to the university. The Open City can form the model of "unconditional university" (Derrida), but also the Latour's "resistant object" (the problem of the group's separation from the socio- political reality in the time of A. Pinochet's dictatorship).

KEYwORDs: Amereida, Latin America, travesia, the Open City, university 